\title{
The potential protective antidiabetic effect of inosine in type 1 diabetic mice
}

\author{
Saad M. El-Sekelly And Salah El-Din A. El-Sayed* \\ Departments of Biochemistry and Physiology*, Faculty of Medicine \\ El-Minia University
}

\begin{abstract}
Inosine -a naturally occurring purine- was long considered to be an inactive metabolite of adenosine. However, recently inosine has been shown to be an immunomodulator and anti-inflammatory agent. The aim of the present study was to determine whether inosine can affect the development of type 1 diabetes in mice. Type 1 diabetes was induced chemically by multiple low doses of streptozotocin. (MLDS). Mice were treated with inosine (100 or $200 \mathrm{mg} / \mathrm{kg} / \mathrm{day}$ ) and diabetes incidence was monitored. The effect of inosine on oxidative stress also was determined. The results showed that inosine reduced the incidence of diabetes in streptozotocin-induced diabetes and also decreased the oxidative stress. The purine exerts anti-inflammatory effects in the pancreas, which is its likely mode of action. The use of inosine should be considered as a potential preventive therapy in humans susceptible to develop Type 1 diabetes.
\end{abstract}

\section{INTRODUCTION}

It is well known that certain naturally occurring purines can exert a powerful modulatory effects on the immune system. The nucleoside adenosine is the best characterized of these purines and has been shown to affect almost all aspects of an immune response ${ }^{(1-3)}$. Adenosine and its analogs can affect the development of a variety of inflammatory diseases including endotoxic $\operatorname{shock}^{(4)}$, rheumatoid arthritis $^{(5)}$, pleural inflammation $^{(6)}$, nephritis ${ }^{(7)}$, uveitis $^{(8)}$, and colitis ${ }^{(\mathbf{9})}$. Adenosine's effects are partly mediated by the inhibition of deleterious immune-mediated processes, including the release of pro-inflammatory cytokines and free radicals $^{(\mathbf{1 0})}$. Inosine is a naturally occurring purine, formed from the breakdown of adenosine by adenosine deaminase ${ }^{(\mathbf{1 1 )}}$.

Although inosine was widely believed to be inert, it had been demonstrated that inosine inhibits the release of pro-inflammatory cytokines and chemokines by activated murine macrophages $^{(12)}$, and that such compound exerts a powerful -in vivoanti-inflammatory effects in murine endotoxic shock $^{(12,13)}$, colitis ${ }^{(9)}$, septic shock $^{(14)}$, and severe lung inflammation $^{(\mathbf{1 5 )}}$. Inosine also has antiinflammatory effects on human cells in vitro, reducing tumor necrosis factor- $\alpha$ (TNF- $\alpha$ ) and interleukin (IL)$1 \beta$ production by monocytes and epithelial cells in response to lipopolysaccharide treatment, as well as inhibiting super oxide radical 
production by activated human neutrophils $^{(\mathbf{1 6})}$.

Type 1 diabetes is a disease characterized by the specific destruction of insulin-producing $\beta$ cells in the pancreatic islets of Langerhans by the immune system ${ }^{(\mathbf{1 7})}$. The islet is invaded by immune cells, particularly macrophages and $\mathrm{T}$ cells, and these cells are cytotoxic to islet $\beta$ cells, in part by generating cytokines and free radicals (18). It has been proposed that the insulitis lesion is $\beta$ cell destructive when Th1 cytokines (IL-12, interferon (IFN)- $\gamma$, IL-1, and TNF- $\alpha$ ) produced by islet infiltrating macrophages and $\mathrm{T}$ cells dominate over Th2 cytokines (IL-4, IL-10) ${ }^{(\mathbf{1 9})}$.

There are 2 murine models of autoimmune diabetes: the multiple low doses streptozotocin (MLDS) model and the spontaneous non obese diabetic (NOD) mouse model. The MLDS model of diabetes is characterized by a progressive hyperglycemia and insulitis similar to that observed in human subjects with recent-onset type 1 diabetes $^{(20,21)}$. The NOD mouse model also shares clinical, serological, and histoimmunological features with human type 1 diabetes ${ }^{(22)}$. Both models have been used extensively to study the preventive therapies for type 1 diabetes $^{(22,23)}$. A variety of procedures and therapies that delete, suppress, or modulate the functions of the immune system cells can block the autoimmune response against islet $\beta$ cells and prevent $\beta$-cell destruction and may even reverse established diabetes in the NOD mouse ${ }^{(24,25)}$.

In view of the finding that inosine is a potent immuno-modulating

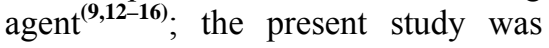

designed to test the potential effects of inosine in MLDS model of type 1 diabetes.

\section{MATERIALS \& METHODS}

\section{Materials}

Reagents were obtained from the following sources. Streptozotocin and sodium citrate were obtained from Sigma (St. Louis, MO, USA). Insulin was measured by immunometric assay according to the protocol of Immulite (Diagnostic Product Corporation, U.S.A) using Immulite Automated Immunoassay Analyzer (Diagnostic Product Corporation, U.S.A) which automates the entire assay process.

\section{Animals}

The current work was done on 50 male mice, weighing 150-250 $\mathrm{g}$ and average 12 weeks old .They were classified into 5 groups, 10 mice in each group. Group 1 (control group), were given water orally (Vehicle) starting on day one. Group II was given inosine alone. Group III was treated with streptozotocin $(40 \mathrm{mg} / \mathrm{kg}$ dissolved in citrate buffer, $\mathrm{pH} 4.5$ ) intraperitoneally for 5 consecutive days. Groups IV and V were treated as group III and at the same time were treated every day starting on day one with inosine 100 and $200 \mathrm{mg} / \mathrm{kg} /$ day respectively.

Blood glucose was measured on days $1,7,14$, and 21 . Hyperglycemia was defined as a non fasting blood glucose level $\geq 140 \mathrm{mg} / \mathrm{dl}$.

Determination of Pancreatic Insulin
and Malondialdehyde.
Insulin contents in pancreas of
mice were determined from a
pancreas biopsy, which was
homogenized in acidified ethanol


(75\% ethanol, $1.5 \% 12 \mathrm{~mol} / \mathrm{L} \mathrm{HCl}$, and $23.5 \% \mathrm{H}_{2} \mathrm{O}$ ), and then incubated for $72 \mathrm{~h}$ at $4{ }^{\circ} \mathrm{C}$ and centrifuged. Care was taken to remove biopsies from the same location of the pancreas (body) to avoid differences between the regions of the pancreas in regards to insulin content. The insulin content of the supernatant was determined using immulite insulin kit (Diagnostic Product Corporation, U.S.A). Pancreatic insulin content was expressed as ng insulin/mg protein, which was determined by the Bradford assay ${ }^{(26)}$.

\section{Malondialdehyde}

(MDA) content was determined from a pancreatic biopsy homogenized in $1.15 \% \mathrm{KCl}$ buffer. Homogenate (200 $\mu \mathrm{L})$ was added to a reaction mixture consisting of $1.5 \mathrm{ml} \quad 0.8 \%$ thiobarbituric acid, $200 \mu \mathrm{L} \quad 8.1 \%$ sodium dodecyl sulfate, $1.5 \mathrm{ml} 20 \%$ acetic acid $(\mathrm{pH} 3.5)$, and $600 \mu \mathrm{L}$ distilledH2O. The mixture was incubated at $90{ }^{\circ} \mathrm{C}$ for $45 \mathrm{~min}$. After cooling to room temperature, the sample was cleared by centrifugation $(10000 \times g, 10 \mathrm{~min})$ and absorbance was measured at $532 \mathrm{~nm}$, using 1,1,3,3-tetra-methoxypropane as an external standard (14). Results were expressed as pmol MDA/mg protein.

\section{Statistical Analyses}

Data were presented as means \pm SD. Statistical analysis was performed using the t-test as appropriate; $P<$ 0.05 was considered significant.

\section{RESULTS}

Table 1 and Figure 1 showed that MLDS treatment induced a progressive hyperglycemia over a 21day period (blood glucose $\geq 140 \mathrm{mg}$ /dL) in mice. Inosine at 100 and 200 $\mathrm{mg} / \mathrm{kg}$ /day significantly reduced the rise in mean blood glucose level at 21 day from $209.4 \pm 11.78$ to $156.85 \pm 9.1(\mathrm{P}<0.001) \quad \&$ and $127.6 \pm 9.3(\mathrm{P}<0.001) \quad$ respectively. Inosine alone had no effect on blood glucose (60.9 \pm 7.8$)$.

Table 1: Blood Glucose Level (mg/ dl)

\begin{tabular}{|l|l|l|l|l|}
\hline & Day 1 & Day 7 & Day 14 & Day 21 \\
\hline Group I & $61.3 \pm 6.4$ & $55.2 \pm 5.4$ & $50.5 \pm 5.7$ & $49.05 \pm 5.1$ \\
\hline Group II & $61.1 \pm 6.13$ & $59.6 \pm 8.2$ & $60.7 \pm 7.9$ & $60.9 \pm 7.81$ \\
\hline Group III & $61.35 \pm 6.4$ & $126.6 \pm 16.32$ & $153.35 \pm 11.2$ & $209.4 \pm 11.78$ \\
\hline Group IV & $60.65 \pm 5.8$ & $97.95 \pm 8.7$ & $124.9 \pm 9.3$ & $156.85 \pm 9.1 *$ \\
\hline Group V & $60.1 \pm 5.17$ & $80.05 \pm 7.65$ & $118.3 \pm 8.7$ & $127.6 \pm 9.3^{* *}$ \\
$* P<0.001$ significant difference between (group IV and III). \\
$* * P<0.001$ significant difference between (group V and III).
\end{tabular}




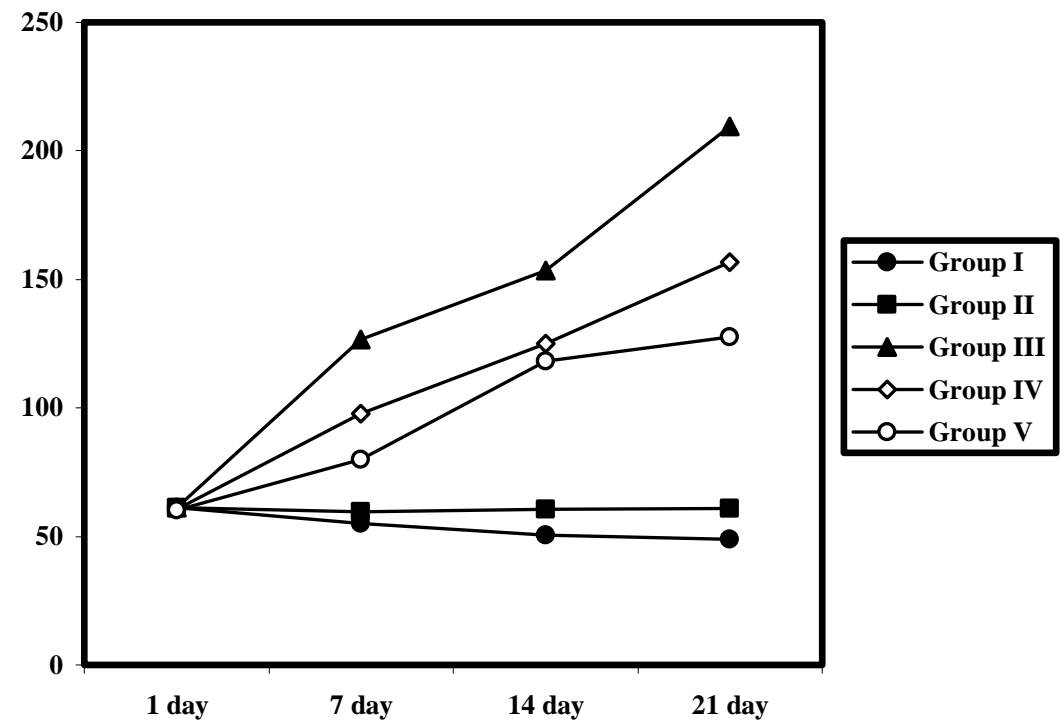

Figure 1: Daily treatment with inosine (100 or $200 \mathrm{mg} / \mathrm{kg} /$ day) for 21 day decreases hyperglycemia following MLDS treatment of mice on days 1 to 7.

Figure $2 \&$ Table 2 showed that MLDS treatment significantly decreased the pancreatic insulin content in mice on day 21 from $79.8 \pm 8.65$ to $16.5 \pm 3.94(\mathrm{P}<0.0003)$. This was significantly increased by inosine treatment $(100 \mathrm{mg} / \mathrm{kg} /$ day and $200 \mathrm{mg} / \mathrm{kg} / \mathrm{day}$ ) from $6.5 \pm 3.94$ to
$34.2 \pm 4.99$ and $53.7 \pm 4.45$ respectively $(\mathrm{P}<0.0001 \& 0.0004$ respectively) . Also, the effect of $200 \mathrm{mg} / \mathrm{kg} /$ day of inosine is significantly higher than the effect of $100 \mathrm{mg} / \mathrm{kg} /$ day of inosine on the pancreatic insulin effect (from $34.2 \pm 4.99$ to $53.7 \pm 4.45)(\mathrm{P}<0.001)$.

Table 2: Pacreatic Insulin Content ( ng insulin / mg protein)

\begin{tabular}{|l|l|l|l|l|l|}
\hline & GROUP 1 & IIROUPG & IIIGROUP & GROUP IV & GROUP V \\
\hline MEAN & 79.8 & 74.8 & $16.5^{*}$ & $34.2^{* *}$ & $53.7^{* * * \dagger}$ \\
\hline SD & 8.65 & 7.64 & 3.94 & 4.99 & 4.45 \\
\hline
\end{tabular}

* $\quad P<0.003$ significant difference between (III and I)

** $P<0.0001$ significant difference between (IV and III)

*** $P<0.0004$ significant difference between ( $V$ and III)

$\dagger \quad P<0.001$ significant difference between ( $V$ and IV) 


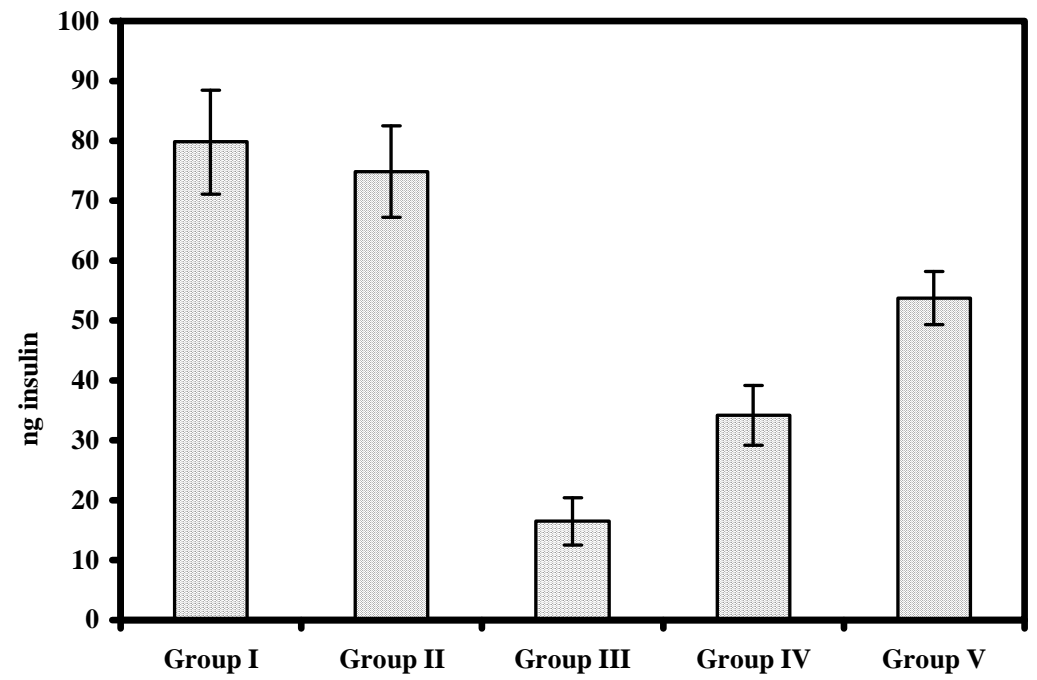

Figure 2. Inosine treatment attenuates the effects of MLDS treatment on pancreatic insulin content.

Table 3 and Figure 3 use MDA formation to quantify lipid peroxidation in the pancreas, a measure of oxidative stress showed that MDA was significantly elevated by MLDS from 204.9 \pm 34.3 to $698.5 \pm 9.47(\mathrm{P}<0.0001)$ and the treatment with inosine $100 \mathrm{mg} / \mathrm{kg} / \mathrm{day}$ had significantly decreased the level of MDA from 698.5 \pm 9.47 to $455.7 \pm 8.3(\mathrm{P}<0.0002)$. Increasing inosine dose from $100 \mathrm{mg} / \mathrm{kg} /$ day to $200 \mathrm{mg} / \mathrm{kg} /$ day had significantly more decreasing effect on the level of MDA. It decreased MDA level from $455.7 \pm 8.3$ to $413 \pm 11.77(\mathrm{P}<0.001)$.

Table 3: Pancreatic MDA ( pmol/mg protein)

\begin{tabular}{|c|c|c|c|c|c|}
\hline & $\begin{array}{c}\text { Control } \\
\text { (GP I) }\end{array}$ & $\begin{array}{c}\text { Inosine } \\
\text { 200mg/kg/day } \\
\text { (GPII) }\end{array}$ & $\begin{array}{c}\text { Streptozotocin } \\
\text { +Vehicle } \\
\text { (GPIII) }\end{array}$ & $\begin{array}{c}\text { SZT+Inosine } \\
100 \text { mg/kg/day } \\
\text { (GPIV) }\end{array}$ & $\begin{array}{c}\text { SZT+Inosine } \\
200 \text { mg/kg/day } \\
\text { (GPV) }\end{array}$ \\
\hline MEAN & 216.7 & 204.9 & $698.5^{*}$ & $455.7^{* *}$ & $413 * * *$ \\
\hline SD & 12.3 & 34.3 & 9.47 & 8.3 & 11.77 \\
\hline
\end{tabular}




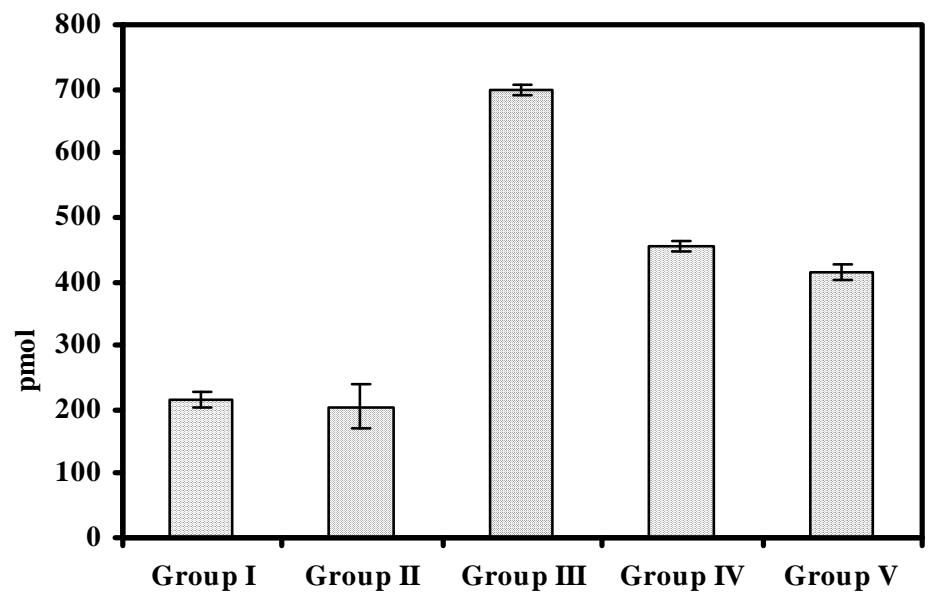

Figure3. MDA formation was used to quantify lipid peroxidation in the pancreas.

\section{DISCUSSION}

The present study in the MLDSinduced model of type 1 diabetes demonstrated that inosine dosedependently protects against hyperglycemia and significantly reduces the incidence of diabetes. Doses of inosine under $100 \mathrm{mg} / \mathrm{kg} /$ day appear to be ineffective in protecting against MLDS-induced diabetes. Previous studies showed similar effects on colitis $^{(9)}$, endotoxic or septic shock $^{(12,14)}$, and lung inflammation ${ }^{(15)}$. Inosine was effective only at dosages greater than $100 \mathrm{mg} / \mathrm{kg}$ /day. Previous reports revealed that inosine had marked anti-inflammatory effects, both in vitro and in vivo in acute inflammatory conditions $^{(\mathbf{9 , 1 2}-\mathbf{1 6})}$. Inosine reduced pancreatic infiltration by polymorphonuclear leukocytes and monocytes resulting in decreased pancreatic damage (lipid peroxidation) and a greater survival of $\beta$ cells. The effects of inosine appeared to be via a reduction of the pancreatic levels of the Th1 cytokines (IL-12, IFN- $\gamma$, TNF- $\alpha$ ). However, inosine failed to reduce pancreatic levels of IL-1. The cytokines IFN- $\gamma$, TNF- $\alpha$, and IL-1 all have been implicated in $\beta$-cell functional inhibition, destruction, and autoimmune diabetes ${ }^{\mathbf{( 1 8 , 2 8})}$.

Also, IL-12 expression has been correlated with development of diabetes in the NOD mouse ${ }^{(\mathbf{2 9})}$ and treatment of NOD mice with an IL-12 antagonist-suppressed diabetes development and decreased pancreatic expression of mRNA for IFN- $\gamma^{(30)}$.

Previous -in vitro- experiments have demonstrated inhibition of Th1 cytokines by inosine, without any increase in Th2 cytokine production from macrophages stimulated with lipopolysaccharide ${ }^{(\mathbf{1 2})}$. In contrast, in endotoxemic mice inosine not only significantly reduced Th1 cytokine 
levels but also increased the levels of Th2 cytokines ${ }^{(\mathbf{1 2})}$, suggesting that inosine's overall effect is a shift from a Th1- to a Th2-type cytokine profile.

A chemical form of inosine, inosine pranobex, has been reported previously to be partially protective against hyperglycemia in the MLDSinduced model of diabetes ${ }^{(31)}$. Based on the current results, we believe that the protective effects of inosine pranobex $^{(31)}$ are related to the inosine component. It is noteworthy that in some countries inosine pranobex has been approved for the treatment of humans with various inflammatory conditions including hepatitis and arthritis, and in humans, the doses of the compound range from $3 \mathrm{~g} / \mathrm{d}$ to 200 $\mathrm{mg} / \mathrm{kg} /$ day $^{(32,33)}$.

The effects of inosine on inflammatory cytokine and chemokine production were proposed to be mediated, at least in part, by adenosine-receptor related mechanisms $^{(\mathbf{1 2})}$. Activation of the adenosine A2a receptor has been shown to down regulate inflammation and protect against tissue damage ${ }^{(34)}$. Inosine treatment markedly reduced the early inflammatory reaction elicited by an islet xenograft and substantially prolonged the graft survival. Therefore, such an approach may form an important future component of therapeutic regimens applied in clinical islet xenotransplantation $^{(35)}$. Inosine may deserve further evaluation for its potential hyperoxic. Inosine treatment during hyperoxic exposure reduce damage to the pulmonary alveolar epithelium $^{(36)}$. Inosine reduced the severity of acute pancreatitis, suggesting a possible application of that compound in the treatment of acute pancreatitis $^{(37)}$.

The use of specific inhibitors for that receptor subtype has demonstrated that inosine's inhibitory effect on inflammatory cytokine production is mediated in part by activation of the adenosine receptor $^{(12)}$. It is also possible that inosine produces its inhibitory effects on cytokine production via binding to adenosine A3 receptors shown to be present on monocytes and macrophages $^{(38)}$. However, no specific rodent A3 receptor antagonist has been tested so far to investigate that possibility $^{(\mathbf{1 2})}$. It is, also, possible that part of the anti-inflammatory effects of inosine are not mediated by adenosine receptor activation but, rather, by other mechanisms ${ }^{(\mathbf{1 2})}$. It has been established that production of proinflammatory cytokines can be regulated at the translational level. For example, tetracycline ${ }^{(39)}$, metalloproteinase inhibitors ${ }^{(40)}$, and polyamines $^{(41)}$ all suppress the production of inflammatory mediators without affecting transcriptional events. The post-transcriptional nature of inosine's mechanism of action would be preferable to transcriptional inhibitors, because it would be expected to increase the window of therapeutic opportunity, and may remain effective even in a posttreatment paradigm.

Other data has, also, indicated that inosine at millimolar concentrations in vitro can inhibit the enzyme, poly (ADP-ribose) polymerase $^{(42)}$, an enzyme implicated in the pathogenesis of various forms of inflammation including autoimmune diabetes ${ }^{(23,43)}$. We do not 
know whether the concentrations of inosine achieved in this study in vivo reached levels at which a significant inhibition of poly (ADP-ribose) polymerase could have accounted for the protective effects of inosine against diabetes.

Inosine has been shown to be more than just an "inactive" metabolite of adenosine, acting not only as an anti-inflammatory agent $^{(\mathbf{9 , 1 2 - 1 6 )}}$, but also, preventing glial cell death during glucose deprivation $^{(44)}$, decreasing the release of intracellular enzymes from hypoxic lymphocytes $^{(45)}$, improving renal function during ischemia ${ }^{(46)}$, and removing the harmful effects of total hepatic ischemia ${ }^{(47)}$. Inosine, also, reduced the severity of acute pancreatitis, suggesting a possible application of that compound in the treatment of acute pancreatitis ${ }^{(\mathbf{4 8})}$ and protecting against allergic encephalomyelitis $^{(49)}$.

As described above, the mechanism through which inosine exerts its anti-inflammatory effect is still unclear, and likely to employ multiple mechanisms. An additional mechanism, recently highlighted by studies in murine encephalomyelitis models, may be related to direct antioxidant effects: inosine is broken down in vivo to produce uric acid, and uric acid has potent antioxidant properties against peroxynitrite and other reactive oxygen species ${ }^{(49)}$. Therefore, at least some of the therapeutic effects, particularly on the inflammatory processes and possibly islet cell damage could be mediated by the antioxidant action of uric acid. In fact, the protective effects of uric acid in a variety of models of inflammation are now well established $^{(50)}$. Future testing of the effect of uric acid in the NOD model of diabetes may directly address that question.

Inosine is a safe, naturally occurring purine, which appears to be nontoxic to humans, even when ingested at high doses ${ }^{(51)}$. Inosine has recently been used in small patient populations for the therapy of multiple sclerosis ${ }^{(52)}$. With an increasing body of pre clinical evidence showing that inosine is effective in a wide variety of inflammatory diseases, it may be worthwhile re-evaluating its therapeutic potential in humans suffering from a variety of inflammatory and autoimmune diseases.

\section{REFERENCES}

1. Cronstein BN. (1994): Adenosine, an endogenous antiinflammatory agent. J.Appl. Physiol., 76:5-13.

2. Apasov S, Koshiba M, Redegeld F and Sitkovsky MV. (1995): Role of extra cellular Append P1 and P2 classes of purinergic receptors in T-cell develop-pment and cytotoxic $\mathrm{T}$ lymphocyte effector functions. Immunol. Rev., 146:5-19.

3. Hasko G and Szabo C. (1998): Regulation of cytokine and chemokine production by transmitters and co-transmitters of the autonomic nervous system. Biochem.Pharmacol., 56:107987.

4. Hasko G, Nemeth ZH, Vizi ES, Salzman AL and Szabo C. (1998): An agonist of adenosine 
A3 receptors decreases interleukin-12 and interferon- $\gamma$ production and prevents lethality in endotoxemic mice. Eur. J. Pharmacol., 358:261-8.

5. Szabo C, Scott GS, Virag $L$ and Hasko G. (1998): Suppression of macrophage inflammatory protein (MIP)- $1 \alpha$ Production and collagen-induced arthritis by adenosine receptor agonists. $\mathrm{Br}$. J. Pharmacol., 125:379-87.

6. Schrier DJ, Lesch ME, Wright CD and Gilbertsen RB. (1990): The anti-inflammatory effects of adenosine receptor agonists on the carrageen an-induced pleural inflammatory response in rats. $J$. Immunol., 145:1874-9.

7. Poelstra K, Heynen ER, Baller JF, Hardonk MJ and Bakker WW. (1992): Modulation of anti-Thyl nephritis in the rat by adenine nucleotides. Evidence for an anti inflammatory role for nucleotidases. Lab. Invest., 66:555-63.

8. Marak Jr GE, de Kozak Y., Faure JP and Till GO (1988): Pharmacologic modulation of acute ocular inflammation. I Adenosine. Ophthalmic Res., 20(4):220-6.

9. Mabley JG, Pacher $P$ and Salzman AL. (2003): Inosine reduces inflame-mation and improves survival in a murine model of colitis. Am. J. Physiol. Gastrointest. Liver Physiol., 284:G138-44.

10. Hasko G, Kuel DG., and Szabo C. (2000): Adenosine inhibits IL12 and TNF- $\alpha$ production via adenosine A2a receptordependent and independent mechanisms. FASEB J., 14:206574.

11. Barankiewicz J and Cohen A. (1985): Purine nucleotide metabolism in resident and activated rat macrophages in vitro. Eur. J. Immunol., 15:62731.

12. Hasko G., Kuel DG. And Salzman AL. (2000): Inosine inhibits inflammatory cytokine production by a posttranscriptional mechanism and protects against endotoxininduced shock. J. Immunol., 164:1013-9.

13. Garcia Soriano F., Liaudet L., Marton A. And Hasko G. (2001): Inosine improves gut permeability and vascular reactivity in endotoxic shock. Crit. Care Med. 29:703-8.

14. Liaudet L., Mabley JG., Soriano FG., and Pacher $P$. (2001): Inosine reduces systemic inflammation and improves survival in septic shock induced by cecal ligation and puncture. Am. J. Respir. Crit Care Med, 164(7):1213-20.

15. Liaudet L., Mabley JG., Pacher P., Deitch EA and Szabo C. (2002): Inosine exerts a broad range of anti-inflammatory effects in a murine model of acute lung injury. Ann. Surgery 235:568-78.

16. Marton A., Patcher P., Murthy KG., Nemeth ZH and Szabo C. (2001): Anti-inflammatory effects of inosine in human monocytes, neutrophils and epithelial cells in vitro. Int. J. Mol. Med., 8:617-21. 
17. Bach J-F. (1994): Insulindependent diabetes mellitus as an autoimmune disease. Endocr. Rev., 15:516-42.

18. Rabinovitch A and SuarezPinzon WL. (1998): Cytokines and their roles in pancreatic islet $\beta$-cell destruction and insulindependent diabetes mellitus. Biochem. Pharmacol., 55:113949.

19. Rabinovitch A. (1998): An update on cytokines in the pathogenesis of insulindependent diabetes mellitus. Diabetes Metab. Rev., 14:129-51.

20. Like AA and Rossini AA. (1976): Streptozotocin induced pancreatic insulitis: new model of diabetes mellitus. Science 193:415-7.

21. Rossini AA, Williams RM, Appel MC and Like AA. (1978): Complete protection from low-dose streptozotocin-induced diabetes in mice. Nature 276:1824.

22. Atkinson MA and Leiter EH. (1999): The NOD mouse model of type 1 diabetes: as good as it gets? Nat. Med., 5:601-4.

23. Mabley JG., Suarez WL., Hasko G., Szabo C.And Kune E. (2001): Inhibition of poly (ADP-ribose) synthetase by gene disruption or inhibition with 5iodo-6-amino-1,2-benzopyrone protects mice from multiple low dose streptozotocin-induced diabetes. Br. J. Pharmacol., 133:909-19.

24. Chatenoud L, Primo $J$ and Bach JF. (1997): CD3 antibodyinduced dominant self tolerance in overtly diabetic NOD mice. $J$. Immunol., 158:2947-54.

25. Ryu S, Kodama S, Ryu K, Schoenfeld DA and Faustman DL. (2001): Reversal of established autoimmune diabetes by restoration of endogenous beta cell function. J. Clin. Invest., 108:63-72.

26. Bradford MM. (1976): A rapid and sensitive method for the quantification of microgram quantities of protein utilizing the principle of protein-dye binding. Anal. Biochem., 72:248-54.

27. Mabley JG, Virag $L$ and Szabo C. (2002): Role of poly (ADPribose) polymerase activation in the pathogenesis of diabetes mellitus and diabetic vascular dysfunction. In: PARP as a therapeutic target. Zhang J (ed.) CRC Press, London, pp. 277319.

28. Eizirik DL and Darville MI. (2001): $\beta$-cell apoptosis and defense mechanisms: lessons from type 1 diabetes. Diabetes, 50 (Suppl)1:S64-9.

29. Abinovitch A, Suarez-Pinzon WL and Sorensen O. (1996): Interleukin 12 mRNA expression in islets correlates with $\beta$-cell destruction in NOD mice. $J$. Autoimmun., 9:645-51.

30. Rothe H, O'Hara Jr RM, Martin S, Kolb H. (1997): Suppression of cyclophosphamide induced diabetes development and pancreatic Th1 reactivity in NOD mice treated with the interleukin (IL)-12 antagonist IL-12 (p40)2. Diabetologia, 40:641-6. 
31. Kolb H., Oschiilewski M., Schwab E., Burkart V. And Zielasek J. (1987): Analysis of 22 immunomo-dulatory substances for efficacy in lowdose streptozotocin-induced diabetes. Diabetes Res., 6:21-7.

32. Wybran J, Famaey JP and Appelboom T. (1981): Inosiplex: a novel treatment in rheumatoid arthritis? J. Rheumatol., 8:643-6.

33. Campoli-Richards DM, Sorkin EM, and Heel RC. (1986): Inosine pranobex. A preliminary review of its pharmacodynamic and pharma-cokinetic properties, and therapeutic efficacy. Drugs, 32:383-424.

34. Ohta A and Sitkovsky $M$. (2001): Role of G-proteincoupled adenosine receptors in down regulation of inflammation and protection from tissue damage. Nature, 414:916-20.

35. Leung GP, Man RY and Tse CM (2005): D-Glucose up regulates adenosine transport in cultured human aortic smooth muscle cells. Am J Physiol Heart Circ Physiol., 288 (6): H2756-62.

36. Buckley S, Barsky L, Weinberg $K$ and Warburton D. (2005): In vivo inosine protects alveolar epithelial type 2 cells against hyperoxia-induced DNA damage through MAP kinase signaling. Am J Physiol Lung Cell Mol Physiol., 288(3):L569-75

37. Yamagiwa $T$, Shimosegawa $T$, Satoh A, Kimura K, Sakai Y and Masamune A (2004): Inosine alleviates rat caerulein pancreatitis and pancreatitisassociated lung injury. J Gastroenterol., 39(1):41-9.
38. McWhinney CD., Dudley MW., Bowlin TL. and Edwards CK. (1996): Activation of adenosine A3 receptors on macrophages inhibits tumor necrosis factor- $\alpha$. Eur. J. Pharmacol., 310:209-16.

39. Shapira L, Houri Y, Barak V, Soskolne WA, Halabi A and Stabholz A. (1997): Tetracycline inhibits Porphy-romonas gingivalis lipopolys-accharideinduced lesions in vivo and TNF$\alpha$ processing in vitro. $J$. Periodontal Res., 32:183-8.

40. Mohler KM., Paul R., Sleath PR., Fitzner JN., and Wearawarna K. (1994): Protection against a lethal dose of endotoxin by an inhibitor of tumor necrosis factor processing. Nature 370:218-20.

41. Zhang M., Theresa C., Haichao W., Pamela S. and Kevin J. T. (1997): Spermine inhibits proinflammatory cytokine synthesis in human mononuclear cells: a counter-regulatory mechanism that restrains the immune response. J. Exp. Med., 185:1759-68.

42. Virag $L$ and Szabo C. (2001): Purines inhibit poly (ADP-ribose) polymerase activation and modulate oxidant-induced cell death. FASEB J., 15:99-107.

43. Mabley JG., Jagtab P., Perretti M.and Marton A. (2001): Antiinflammatory effects of a novel, potent inhibitor of poly (ADPribose) polymerase. Inflamm. Res., 50:561-9.

44. Jurkowitz MS, Litsky ML, Browning MJ and Hohl CM. (1998): Adenosine, inosine, and guanosine protect glial cells 
during glucose deprivation and mitochondrial inhibition correlation between protection and ATP preservation. $J$. Neurochem., 71: 535-48.

45. Cole AW and Palmer TN. (1979): Action of purine nucleosides on the release of intracellular enzymes from rat lymphocytes. Clin. Chim. Acta 92:93-100.

46. de Rougemont $D$, Brunner FP, Torhorst J, Wunderlich PF and Thiel G. (1982): Superficial nephron obstruction and medullary congestion after ischemic injury: effect of protective treatments. Nephron 31:310-20.

47. Tilser I, Martinkova $J$ and Chladek J. (1993): The effect of metipranolol and inosine on total hepatic ischemia of rats in vivo. $\mathrm{Sb}$ Ved Pr Lek Fak Karlovy Univerzity Hradci Kralove 36:259.

48. Yamagiwa $T$, Shimosegawa $T$, Satoh A, Kimura K, Sakai Y and Masamune A. (2004): Inosine alleviates rat caerulein pancreastitis and pancreatitis- associated lung injury. $J$

Gastroenterol., 39(1):41-9.

49. Scott GS, Spitsin SV, Kean RB, Mikheeva T, Koprowski $H$ and Hooper DC. (2002): Therapeutic intervention in experimental allergic encephalomyelitis by administration of uric acid precursors. Proc. Natl. Acad. Sci. U.S.A 99:16303-8.

50. Scott GS and Hooper DC. (2001): The role of uric acid in protection against peroxynitritemediated pathology Med. Hypotheses., 56:95-100.

51. Williams MH., Kreider RB., Hunter DW., Somma CT. and Rokitski L. (1990): Effect of inosine supplementation on 3mile treadmill run performance and VO2 peak. Med. Sci. Sports Exerc., 22:517-22.

52. Spitsin S., Hooper D C., Leist T., Streletz L J. and Koprowskil H. (2001): Inactivation of peroxynitrite in multiple sclerosis patients after oral administration of inosine may suggest possible approaches to therapy of the disease. Mult. Scler., 7:313-9. 


\title{
التاثير الواقى المضاد لمرض البوال السكرى (ألانوسين) فى فئران مصابة

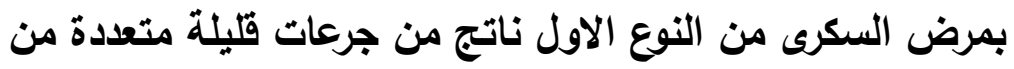 الستريتوزوتوزين
}

\author{
د سعد محد الصقلي 1 و د صلاح الدين عزيز السيد²
}

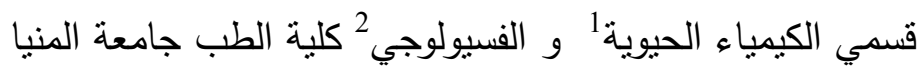

كان الاينوسين -أحد أنواع البيورين- يعتبر لفترة طويلة مادة خاملة ناتجة من التثثيل الغذائى التئ

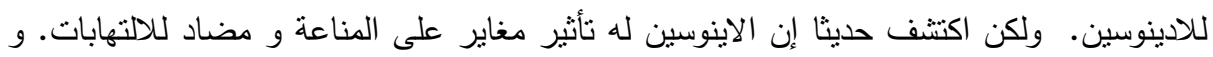

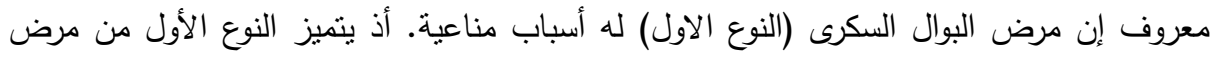
البوال السكرى بتكسير لخلايا بيتا الموجودة في جزر لانجرهانز في البنكرياس بسبب الجهاز المناعبالذى يهاجم الجزر بالخلايا المناعية. هذه الخلايا سامة للجزر وذللك عن طريق إفراز السيتوكين والثقائق الحرة.

الغرض من هذه الدراسة هو بحث دور الاينوسين فى وقاية خلايا البنكرياس من التاثير السام

للجهاز المناعى على خلاياه باستخدام فئران لديها مستحثة تجريبيا بمرض البوال السكرى نتيجة

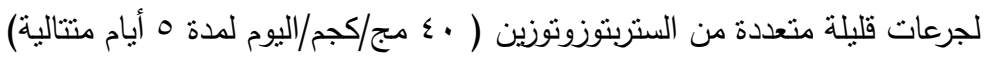

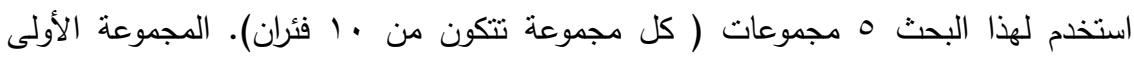

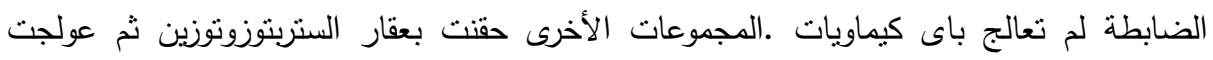
المجموعة الثالثة بماء لمدة لب يوما. المجموعة الرابعة عولجت بالانوسين بتركيز . ـامج/كجم/اليوم

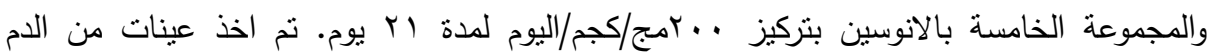

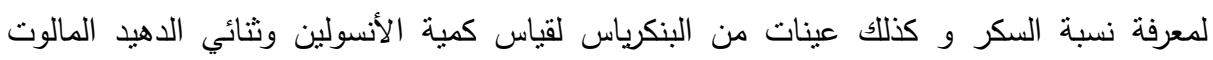

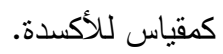

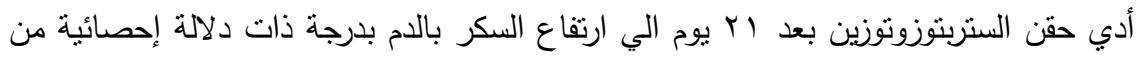

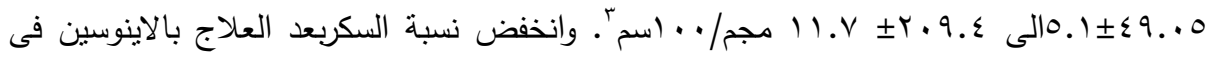

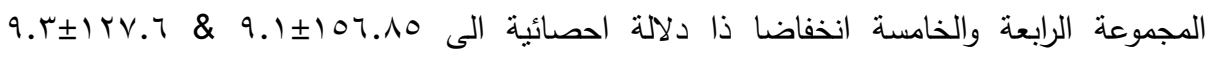

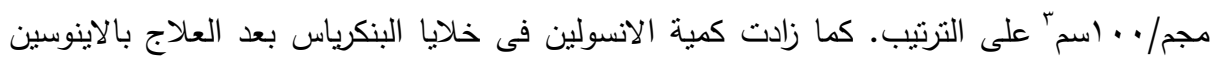

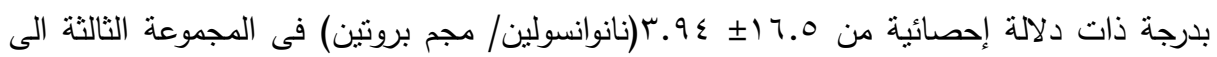


ث

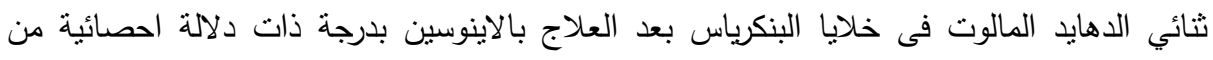

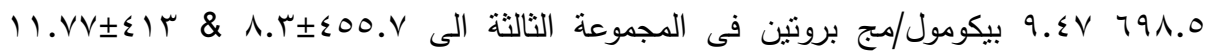
بيكومول/مج بروتين على الترتيب.

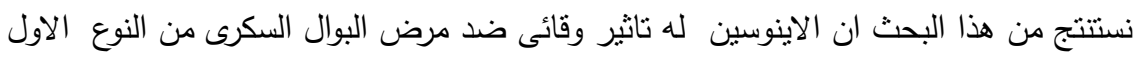

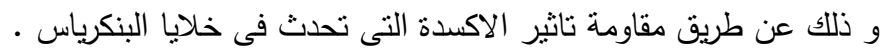

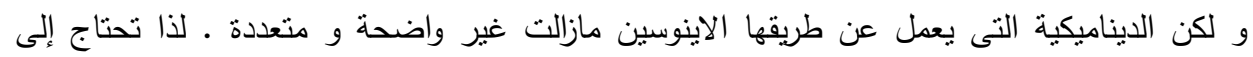

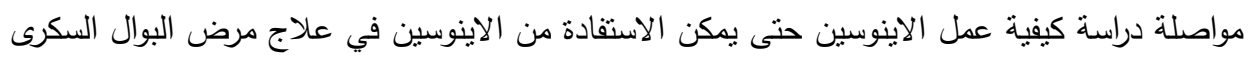

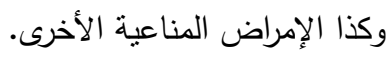

